doubt this aphid ras a complicated life cycle involving a secondary host. Its presence on cottonwood is well known but the damage to the host trees is not considered extensive or serious; consequently, detailed efforts to study its life history in our region for the purpose of formulating control measures have not been undertaken."

P. A. Taverner in his Birds of
Western Canada, 1926, says that Red Crossbills "seem specially fond of the little woolly aphis. It was very interesting to watch a captive specimen open galls on poplar leaves. Seizing the fleshy tissue with the bill tips so that the points crossed within the mass, it gave a little twist of the head that split the gall wide open and the aphids within were removed with the tongue."

\title{
Golden Eagles Preying on Porcupines
}

\section{By Lawrence Ostoforoff, Sask. Museum of Nat. History}

Arthur C. Bent, in Life Histories of North American Birds of Prey, Part I, 1937, page 304, lists the porcupine as a food item of the Golden Eagle (Aquila chrysaëtos). On page 306 Bent gives the following example: "This bold bird sometimes 'catches a 'Tartar.' Albert Lano (1922) had one brought to rim that had attacked a porcupine; 'it was literally covered underneath with quills. In fact there were a number of quills in the roof of its mouth. The body was much emaciated and many of the quills had penetrated deep into the flesh causing pus to form'."

Among Golden Eagle specimens examined by museum staff in recent years, three specimens showed contact with porcupines. One immature female Golden Eagle shot at Milden, Saskatchewan, December, 1958, had approximately a hundred porcupine quills imbedded in its feet. Its right foot had 62 quills, the left foot 33 quills, most of which were bitten off or torn off close to the flesh. Five quills were deeply imbedded in the roof of the mouth, and the gizzard contained a loose mass of quills, lying parallel and enclosed with soft hair, in somewhat the same manner as a pellet. Six quills were very slightly attached to the gizzard lining; none was imbedded deeply and none was found in other parts of the intestinal tract. The bird was very thin; weight: 6 pounds, 8 ounces.

F. W. Lahrman, while mounting an immature Golden Eagle shot at Bethune, Saskatchewan, November, 1950 , noted some quills lying underneath the leg muscle close to the bone. In addition several quills were

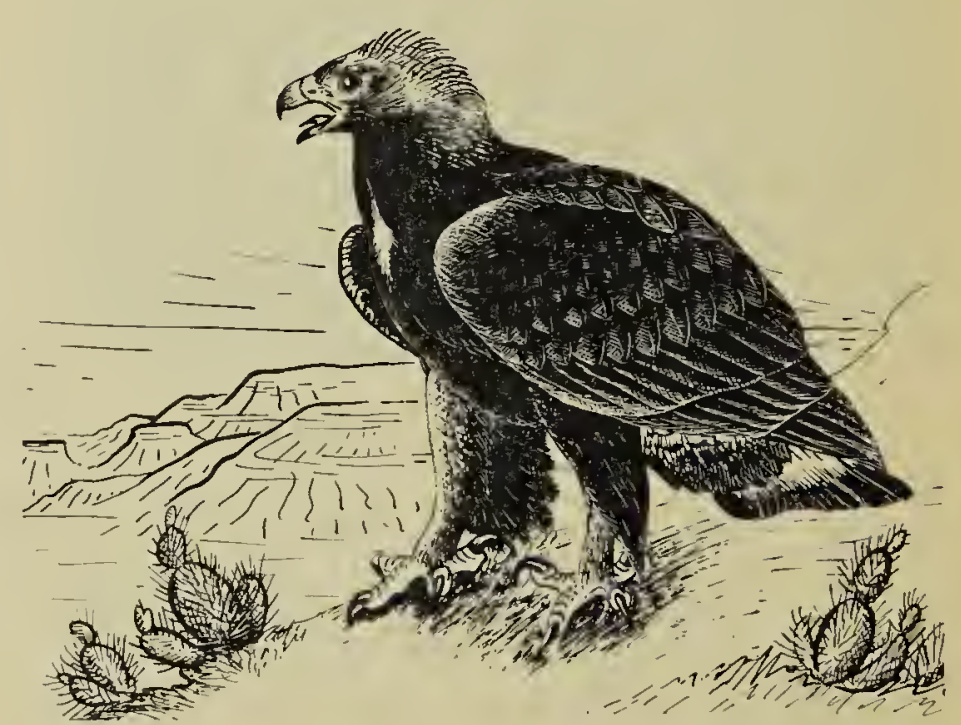

Sketch by $L$. Ostoforoff

found which penetrated the gizzard from the outside. This bird was also very thin.

The third eagle, examined at Mervin, Saskatchewan, by B. C. Shier of the Museum, was so crippled by quills in its feet and mouth that it could no longer hunt its natural prey. It made its way into a chicken coop where it was shot while feeding on a fowl.

Although porcupines are rather common on the Northern Plains, predation by Golden Eagles is probably still a rare occurrence. It is interesting to note that the three Saskatchewan specimens described above were all immature birds, perhaps inexperienced in hunting their usual prey. The dark, slow-moving porcupine on the open prairie-would likely be tempting prey for the young, unwary eagle. 